University of Wollongong

Research Online

Faculty of Law, Humanities and the Arts Papers (Archive)

Faculty of Arts, Social Sciences \& Humanities

$1-1-2013$

Indian movies, brand Australia and the marketing of Australian cosmopolitanism

Andrew Hassam

University of Wollongong, ahassam@uow.edu.au

Follow this and additional works at: https://ro.uow.edu.au/lhapapers

Part of the Arts and Humanities Commons, and the Law Commons

Research Online is the open access institutional repository for the University of Wollongong. For further information contact the UOW Library: research-pubs@uow.edu.au 


\title{
Indian movies, brand Australia and the marketing of Australian cosmopolitanism
}

\begin{abstract}
Indian movies shot overseas have attracted the attention of not only advertising agencies keen to see their clients' brands appearing on-screen, but also government tourism commissions eyeing India's growing middle classes as potential visitors. Australian federal and state governments offer Indian film producers financial incentives to film in Australia, and Australian cities now regularly supply Indian movies with backdrops of upmarket shopping malls, stylish apartments and exclusive restaurants. Yet in helping to project the lifestyle fantasies of India's new middle classes, Australian government agencies are supporting an Indian view of Australia. While this image may attract Indian tourists to Australia, it presumes Australia is culturally White and British, and as a result Australian agencies market an Australian cosmopolitanism defined not in terms of cultural diversity but in terms of the availability of global brands. The absence of cultural diversity in how Australia is branded in Indian movies is at heart a political rather than a marketing issue and one that can be challenged effectively only by holding to account those who are politically responsible for branding the nation.
\end{abstract}

\section{Keywords}

movies, cosmopolitanism, indian, australia, marketing, brand, australian

Disciplines

Arts and Humanities | Law

\section{Publication Details}

Hassam, A. (2013). Indian movies, brand Australia and the marketing of Australian cosmopolitanism. Australasian Journal of Popular Culture, 2 (3), 335-349. 
Indian movies, brand Australia and the marketing of Australian cosmopolitanism Andrew Hassam, University of Wollongong

\begin{abstract}
Indian movies shot overseas have attracted the attention of not only advertising agencies keen to see their clients' brands appearing on-screen, but also government tourism commissions eyeing India's growing middle classes as potential visitors. Australian federal and state governments offer Indian film producers financial incentives to film in Australia, and Australian cities now regularly supply Indian movies with backdrops of upmarket shopping malls, stylish apartments and exclusive restaurants. Yet in helping to project the lifestyle fantasies of India's new middle classes, Australian government agencies are supporting an Indian view of Australia. While this image may attract Indian tourists to Australia, it presumes Australia is culturally White and British, and as a result Australian agencies market an Australian cosmopolitanism defined not in terms of cultural diversity but in terms of the availability of global brands. The absence of cultural diversity in how Australia is branded in Indian movies is at heart a political rather than a marketing issue and one that can be challenged effectively only by holding to account those who are politically responsible for branding the nation.
\end{abstract}


The Tamil movie Unnale Unnale (Jeeva, 2007) is one of at least 50 Indian films appearing between 2000 and 2010 that have used Australia as a backdrop, and the film's depiction of life in Australia illustrates the degree to which the commercial interests of Indian popular cinema and Brand Australia have coalesced around the promotion of a global consumerism. Unnale Unnale deals with a love triangle between three young nonresident Indians (NRIs) living in Melbourne, and the fantasy dance sequences in particular use Australian backdrops to project images of a consumer lifestyle of branded goods and services that has proven so beguiling to the new Indian middle classes.

According to Sudhanva Deshpande, Hindi films have increasingly sought to fulfil the aspirations of those who can afford the higher domestic ticket prices of India's new metropolitan multiplex cinemas or the higher overseas ticket prices of Europe and North America: 'It is not the poor, then, but the globalized rich who, for the most part, create the profits for commercial Hindi cinema. The projection of their fantasies has produced a new kind of hero' (Deshpande 2005: 197). And, for Deshpande, a major feature of their fantasies is a consumerism centred on the hero's body:

he dances like a dream, and his body itself, rather than his persona, is the object of consumption, much to the delight of the advertising world. It is only fitting, then, that this new, consumable hero wears Gap shirts and Nike sneakers, and when he dances, it is in front of McDonald's outlets in white man's land, or Hollywood studios, or swanky trains, and has white girls - not Indian peasants dancing with him. (Deshpande 2005: 197) 
Deshpande's description applies as much to Indian movies set in Melbourne, Perth or Sydney as to those filmed in London, New York or Toronto, and as Jyotsna Kapur and Manjunath Pendakur put it:

The seamless traveling around the globe that is represented in these films confirms the lives and aspirations of the upper sections of the Indian international professional and managerial middle class, a group that services global business, travels frequently, and consumes the same brands as their international counterparts. (Kapur and Pendakur 2007: 51)

Coonoor Kripalani dates product placement in Bollywood from the late 1990s (Kripalani 2006: 204) and, even though audiences for Tamil movies such as Unnale Unnale are predominantly less urbanized than for Hindi movies, as an increasing proportion of boxoffice revenue has come from India's growing middle classes, so popular Indian movies, including Tamil, Telugu and Kannada movies, have become a focus for the advertising world and brand marketing. As Kripalani puts it: 'while audiences are consuming films, consumerism of other goods and services is being sold to them' (Kripalani 2006: 209).

The female counterpart to Deshpande's dance of the consumable hero is the musical shopping spree. Again, despite demographically different audiences, such sequences are as much a feature of Tamil, Telugu and Kannada movies as Hindi movies, witness the shopping malls of Perth in the Kannada movie Preethse (D. Rajendra Babu, 2000). In Unnale Unnale, during the song 'Hello Miss Imsaiyae', one of the film's two 
heroines, Deepika (Tanisha), dances past the Myer department store in Bourke Street twirling Sportsgirl and Accessorize shopping bags while, with perfect timing, a Melbourne tram advertising G-Star Raw Denim clothing passes behind her. In the song 'Vaigasi Nilavae', the film's other heroine, Jhansi (Sadha), emerges in an evening gown from a Diva fashion jewellery store, flanked by a line of women hairdressers; and in a publicity still taken from the film's opening sequence, Jhansi and the hero, Vinay (Karthik), are carefully posed against an entire tram advertisement for L'Oréal cosmetics featuring the brand's 'ambassador', Aishwarya Rai. Rai, a former Miss World and herself a Bollywood megastar, has been a brand ambassador for such global brands as Longines watches, Nakshatra Diamonds, Coca-Cola and Lux soap and, as Goldie Osuri has shown, Rai's image circulates transnationally through complicity with the western discourse of female beauty used to advertise global brands like L'Oréal, 'a transfiguration of an Indian cosmopolitan femininity which can approximate whiteness through appearance and its relationship to consumer goods' (Osuri 2008: 118). Though Rai's face on the Melbourne tram may be advertising cosmetics, framed within Unnale Unnale Rai symbolizes the kind of transnational lifestyle of global brands celebrated in recent Indian movies. Indian movies shot overseas have attracted the attention of not only advertising agencies keen to see their clients' brands associated with the films' stars, but also government tourism commissions eyeing India's growing middle classes as potential visitors. As the Premier of Victoria, Ted Baillieu, put it when announcing the state's success in attracting Bhaag Milkha Bhaag (Mehra, in production) to film in Melbourne: 
As with other Indian films shot in Melbourne, such as Salaam Namaste and Chak de! India, Bhaag Milkha Bhaag will raise our profile in India and showcase Victoria as a great tourism destination. [...] Tourism Victoria will leverage the release of the movie through a marketing campaign in India featuring the key locations from the film. (Premier of Victoria 2012)

This form of destination marketing is regarded by tourism commissions as a more costeffective method of targeting middle-class Indians than the more usual print or television campaign, especially where the target demographic is larger than the entire Australian population. The competition to attract Indian film producers is, however, fierce, both in terms of the number of competitors and the value of the filming incentives offered, as Baillieu noted: 'Mr Baillieu said Film Victoria worked closely with Bhaag Milkha Bhaag's producers to secure filming in Victoria, providing significant location and production services' (Premier of Victoria 2012).

For the past ten or more years, the Australian landscape, particularly the coastline of Victoria's Great Ocean Road, has competed successfully with New Zealand's South Island and the Highlands of Scotland as an alternative to the romantic mountain settings of Switzerland, which themselves had earlier replaced the traditional mountain settings of Kashmir when increasing conflict in the 1980s made it dangerous to film there (Jaisinghani 2004). Australia, of course, can also offer unique tourism images, such as the Great Barrier Reef and kangaroos bounding across a plain, but is less well placed in terms of the more recent demand for backdrops of the global city. New York and London, with their internationally recognizable icons and significant local South Asian audiences, 
remain the first choice of Indian film-makers rather than the less-prestigious and lessrecognizable cities of Australia.

As representations of the global city, Australian cities compete mainly with the newer business hubs of Asia, most notably Bangkok, Singapore and Dubai, cities that may be less prestigious and less recognizable than New York and London, but which can offer cheaper and more accommodating location filming. Melbourne is sold to tourists as 'an exciting, modern metropolis, bustling with award-winning restaurants, hip music venues, cool bars and sensational shopping' (Film Victoria n.d.a.), yet visually this image of Melbourne as a modern metropolis depends not on what makes Melbourne different from other would-be global cities but what makes such cities, from the point of view of an Indian film producer, interchangeable. Essential to the image of the global city are the anonymous, corporate spaces of high-rise office blocks, five-star hotels, executive apartments, up-market restaurants and shopping malls (Hassam 2009: 46-47), hence, for example, the use of shots of Bangkok airport (complete with AOT [Airports of Thailand] signs) to represent Sydney airport in Bachna Ae Haseeno (Anand, 2008). Indeed, international airports are particularly interchangeable as settings and an irony of Tourism Victoria attracting Main Aurr Mrs. Khanna (Soni, 2009) to Victoria - 'a great opportunity to build brand awareness of Melbourne and Victoria in India' (Tourism Victoria 2008) - is that the main Australian setting was the anonymous space of Melbourne airport.

This is not to argue that architectural icons have no role in promoting Australian cities, witness the backdrop of Sydney Harbour Bridge in the picturization of 'Meri Duniya Tuhi Re' in Heyy Babyy (Khan 2007), but the ability to attract Indian productions 
also depends on a city being able to imitate New York or London. Indeed, Film Victoria markets Melbourne precisely for its geographic versatility:

Victoria's easily accessible and geographically diverse locations make it the perfect double for anywhere in the world. [...] Melbourne's history and wide ranging architectural influences have led to a collection of buildings and streetscapes that can double as almost any international location. Our busy streets, tree-lined boulevards and towering skyscrapers have been dressed to double for North American and European cities in the past, present, and future. (Film Victoria 2012)

Such interchangeability accounts for the arrival of Raj Sharma (Ranbir Kapoor) in Sydney in Bachna Ae Haseeno being preceded by an aerial shot of Melbourne or the arrival of Jai Dixit (Emraan Hashmi) in Melbourne in Crook: It's Good To Be Bad (Suri, 2010) being preceded by an aerial shot of New York. Versatility of place makes possible a competitive market for locations, with Sydney, Melbourne and Adelaide competing both with each other and with Bangkok, Dubai and Cape Town to attract Indian filmmakers. In January 2010, Kunal Kohli shifted the filming of Break Ke Baad (Aslam, 2010) from Australia to Cape Town and Mauritius, reportedly in protest at attacks on Indian students in Australia (Anon. 2010), yet he felt able to retain Australia as the narrative setting for the movie, an indication, perhaps, that Australia and South Africa have similar brand images as sunny countries with British colonial and cricketing histories. 
Government tourism commissions, keen to use Indian movies as destination marketing, hope to counter the anonymity of their cityscapes by persuading film-makers to name the locations within the film (Hassam 2010: 182). Of course, films set in Sydney need only include a glimpse of the Harbour Bridge or the Opera House to establish the location, though there may still be some doubling (Heyy Babyy, though set in Sydney, included shots of Brisbane). But Melbourne is dependent on captions and other location markers: Salaam Namaste (Anand 2005) and Unnale Unnale both display a 'Melbourne Australia' caption over initial images of the city, while Nala Damayanthi (Mouli, 2003) includes a Melbourne airport sign. The power of tourism commissions to negotiate the use of such signposting depends on the strength of their filming incentives, which range from assistance with location filming to tax refunds, but government resources are limited and the market in overseas locations favours film producers who can more or less auction the naming rights of the location to the highest bidder. The title of Prateek Chakravorty's latest film was reportedly determined by whether Victoria or NSW offered the better deal:

We have yet to finalise the title of the film. It will definitely include Australia or either Sydney or Melbourne. Our Australian production company [...] is in conversation with the states of Victoria and NSW to explore tie ups before we announce the final name. (Anon. 2011)

As it happens, NSW won and the title became From Sydney ... With Love (Chakravorty, 2012). 
Yet, unlike, say, The Third Man (Reed, 1949) or Blow-Up (Antonioni, 1966), films by overseas directors that seek to examine the character of individual cities at particular moments in time, these Indian movies seek to represent a global consumer lifestyle, and the specificities of place and time are less important than associating Melbourne or Sydney with a culture of conspicuous consumption, witness the way in which Film Victoria publicizes Melbourne as a film location: 'Melbourne is stylish and sophisticated and offers a whole world of food, wine, sports, shopping and nightlife' (Film Victoria n.d.b: 8). Or, to put it another way, the purpose of naming the location as Melbourne, Sydney or Adelaide is less to identify a distinct overseas location than to raise the 'brand awareness' of that city in India in a market oversupplied with similarlooking cities.

Asha Kasebekar sees Dil Chahta Hai (Akhtar, 2001), which was partly set in Sydney, as marking the emergence in Indian cinema of an urban, consumer lifestyle:

What Dil Chahta Hai did was to break free from the rural viewers by concentrating on the urban audiences. It was a film about love - for women, for cars, for consumer goods. And it actively promoted a lifestyle not available to the rural areas. The film indicated changing times and tastes. (Kasebekar 2006: 202)

Kasebekar stresses the promotion of lifestyle rather than consumer goods per se, and, although Australian cities have been sold as branded products by their respective state 
governments, it is important to recognize that the commercial interests of Indian popular cinema and Australian tourist commissions have coalesced not so much around the sale of consumer products as around the marketing of a global lifestyle. This is the difference between the cosmetics advertised by Aishwarya Rai's face on the Melbourne tram and the lifestyle aspirations of the Indian international professional and managerial middle class, as Kapur and Pendakur put it, celebrated by the characters within Unnale Unnale. Indeed, for Finn McKenty, a US marketing designer, the shift from product to lifestyle represents a key development in marketing: 'lifestyle marketing means that you're selling a lifestyle as much as you're selling a product, in contrast to traditional, old-school marketing that's all about the product' (McKenty 2006).

Indian films set in Australia have therefore made a significant contribution to promoting the global lifestyle aspirations of India's new middle classes, including the desire to travel abroad (Anon. 2012b). In seeking to attract tourism, business migration and international students by promoting images of high-rise office blocks, five-star hotels, executive apartments, up-market restaurants and shopping malls, Australian tourism, film and trade commissions have made common cause with Indian film-makers seeking images of the lifestyle aspirations of their audiences. Yet while the lifestyle marketing aim of Australian federal, state and territory governments is to increase trade with India - 'Building brand Australia has an unashamedly commercial focus', as Australia's Trade Minister put it in 2009 (Minister for Trade 2009) - there has been little scrutiny of the consequences of government interests becoming congruent with business, of 'branding the Australian identity and selling Australia to the world' (Minister for Trade 2009). 
In 1951, the Australian Minister for Immigration, Harold Holt, wrote to Thomas White, the Australian High Commissioner in London, in response to complaints appearing in the British press that UK migrants had been misled about the housing and employment conditions in Australia: 'I've little doubt myself that rather too rosy a picture was painted by our [immigration] officers in the first place. Australia and the migration programme appear to have been "sold" rather in a tourist bureau manner' (Joynson 1995: 180). In marketing terms, Holt was discovering how bad publicity could damage nation branding, but his remarks also question how far national identity should be regarded as a commodity to be sold to the world. This is not a question raised by today's Australian politicians, the Australian press or academics in marketing and tourism, all of whom endorse the 'unashamedly commercial' focus of place branding. In order to ask Holt's question, we need to recall what Holt took for granted, that the role of elected politicians is to promote the public good rather than the interests of the marketplace, especially where they may be in conflict, as when, according to one commentator, the romanticized, tourist version of Australia appearing in Indian cinema contributes to the plight of Australia's overseas Indian students: 'Bollywood should stop glamourising Western countries life style. Indian students think that there are rivers of gold flowing in Western countries and that life is easy' (Ashok 2010).

Australia's current brand identity, 'Australia Unlimited', was launched in May 2010, with the claim that the brand was 'a shortcut expression that visually and thematically reflects the way contemporary Australia sees itself, and the way we want to be seen by others' (Australian Trade Commission 2011). The slogan, 'Australia 
Unlimited', was developed by the international advertising agency M\&C Saatchi, which had been awarded a three-year contract to sell Australia to the world in April 2010 (Minister for Trade 2010). Yet, as in the marketing of Australia through Indian movies, the campaign has shown less interest in understanding the way contemporary Australians see themselves than in projecting the way business Australia wants to be seen by others. Indeed, the slogan 'Australia Unlimited' was chosen not by Australians but by 14,000 'consumers' across fourteen 'international markets' (Australian Trade Commission 2012). The 'Australia Unlimited' video does attempt to counter the weight of previous Australian marketing campaigns, as Susie Khamis has noted, by including the faces of 'an extraordinary range of "ordinary" Australians - a range signposted by skin colour, religious dress, and ethnic background' (Khamis 2012: 52); yet, while, as Khamis also notes, 'their inclusion obviously posits Australia's multiculturalism as a marketing asset' (Khamis 2012: 52), the posed photographs of smiling non-White faces do not counter the underlying message contained in the moving images, namely, that to be a doctor, a scientist, an engineer, a pilot, a farmer or a sportsperson, you need to have a white face. Despite the rhetoric of reflecting 'the way contemporary Australia sees itself', Australia's brand identity reflects a majoritarian White viewpoint and, for at least one Australian, avoids contemporary reality: 'Crapo - sooo eighties - sooo self congratulatory - sooo corporate generic. How about more actual - facing up to the challenges of Australia and being Australian' (rwguapa 2011).

Melissa Aronczyk, who wrote a Ph.D. thesis on nation branding, has questioned the use of advertising agencies to project the nation: 
If a public good is by definition an object of democracy, encouraging collective participation from its citizens and procuring just and equitable rewards for the benefit of all, what happens when this public good falls under the authority of private branding and advertising agents? (Aronczyk 2008: 43)

Whereas the public good relates to citizens rather than consumers, a national brand 'ignores the infinite pluralities, conflicts and potentials for resistance that characterize the realities of public life' (Aronczyk 2008: 55). Hence, though nation branding may promote 'wealth' in finance capital, this 'must be accompanied by an understanding of what other forms of collective wealth - self-realization, noninstrumental forms of community, mutual respect - may be lost in the process' (Aronczyk 2008: 56). By focusing on the instrumental benefits of nation branding, governments lose sight of the plurality of communities and the need for conflict and resistance in a healthy democracy. In terms of Australia's appearance in Indian popular cinema, we need to ask what is being lost in the marketing of Australian cities as consumer paradises rather than as socially and culturally diverse communities of citizens.

As we have seen, the concept of diversity is not absent from Brand Australia, and those promoting Australia overseas are keen to emphasize the cultural diversity of Australian cities. This was especially so in the wake of the media attention given to attacks on overseas Indian students in Melbourne in 2009-2010, a public relations crisis that informed the remarks of the Premier of Victoria when promoting Melbourne's Indian film festival in 2011: 'Our government seeks to promote Victoria as a place [...] where film producers can find a variety of people who can speak a range of languages and 
possess a cultural understanding' (State Government of Victoria 2011). In terms of selling Australia, however, the advantage of cultural diversity is not cultural understanding but a cosmopolitan lifestyle, witness the Brand Victoria Resource Book (n.d.): 'In today's world people are searching for cosmopolitan centres like Melbourne which offer lifestyle, security and room to be an individual without judgment or fear' (Victorian Government n.d.: 1.02). Or witness the promotion of a distinctive Sydney lifestyle by the NSW Department of Trade: 'The CBD offers world-class theatres, great shopping, museums and art galleries and restaurants featuring cuisines from around the world' (NSW Department of Trade and Investment, Regional Infrastructure and Services 2012). This is cosmopolitanism for the corporate élite, as characterized by the cultural theorist, Pheng Cheah: 'The cosmopolitanism of corporate workers is essentially the cosmopolitanism of a new technocratic professional class whose primary aims in life are making a profit and conspicuous consumption' (Cheah 2006: 492). Australian cosmopolitanism is sold overseas to those who can afford to buy international brands in upmarket shopping malls and to savour globalized cuisines in stylish restaurants.

In 2011, Tourism Australia launched a marketing campaign based on the experience of Indians visiting Australia, a so-called advocacy-based marketing strategy. According to Nishant Kashikar, Tourism Australia's manager for India: 'The objective of the campaign was to showcase Australia through the eyes of Indians, those who have visited or lived in Oz' (Ahmed 2011). Yet the choice of advocates ensured that their views reinforced Australian branding, with two of the advocates having first visited Australia as actors on overseas shoots: Aditya Hitkari in Aa Ab Laut Chalen (Kapoor, 1999), which featured a romantic song sequence filmed in Perth, and Ram Kapoor in the 
Indian soap, Bade Achhe Lagte Hain (Kapoor, 2011-), which depicts the lead actors honeymooning in Sydney. Not surprisingly, their testimony reinforces the Australian brand image depicted in Indian movies: Aditya Hitkari mimicked the movies by returning to Australia for his own honeymoon (Ahmed 2011), while Ram Kapoor describes his experience as an actor in Bade Achhe Lagte Hain:

Some of the activities that we did like the Ferrari drive and a visit to the SCG [Sydney Cricket Ground] are amongst my personal favourites and experiences that I will cherish always. Filming in Australia has been a fabulous experience and I look forward to visiting again! (Tourism Australia 2011)

The filming of Bade Achhe Lagte Hain was supported by Tourism Australia, which, according to its managing director, Andrew McEvoy, 'contributed \$350,000 towards the soapie for 66 minutes of destination footage across eight 30-minute episodes that will be seen by 25 million Indians' (Upe 2011). As a result, showcasing Australia 'through the eyes of Indians' becomes more a representational closed circuit as an Indian actor attests to the Australia his producer has agreed with Tourism Australia to represent.

There are three reasons why marketing Australia to India with such sleight-ofhand matters. First, the marketing of Australia reinforces a traditional racial opposition between Australia and India by excluding the voices of Australians of Indian descent, a group regarded by both Indian and Australian governments as primarily Indian. Peter Varghese, the Australian High Commissioner to India and himself of Indian descent, commented on the advocacy marketing campaign in a Tourism Australia press release: 
'We wanted people to hear about Australia directly from recent visitors, and from people who have chosen to build their lives in Australia. These authentic Indian voices speak about the many exciting experiences that await you in Australia' (Tourism Australia n.d.). Yet Varghese's reference to 'people who have chosen to build their lives in Australia' as 'authentic Indian voices' marks out the selected advocates as different from those of Indian descent who, like Varghese himself, identify as Australian rather than Indian (Lall 2009). The limited vision of Australia depicted by destination marketing is unable to envisage how some Australians of Indian descent, like Australia's High Commissioner to India, speak with authentic Australian rather than Indian voices and may have a different idea of 'the way contemporary Australia sees itself' from that depicted in tourism advertising.

Second, this blindness towards those of Indian descent who identify with Australia rather than India reinforces the image of a White Australia promoted by Indian movies. In 2009, a month after Bollywood megastar Amitabh Bachchan announced he was declining an honorary degree from Queensland University of Technology because of violence against Indian students studying in Australia (Fraser 2009), the Indian filmmaker, Mohit Suri, announced he would be making a film dealing centrally with racism in Australia: 'I want to show people what instigates all these attacks' (Anon. 2009). Yet the eventual film, Crook (Suri, 2010), merely reiterated the media's view of racism in Australia, that it was solely practiced by White Australians on non-Whites. White men and women have been traditionally the villains in Indian movies - 'the slutty white woman trying to steal the husband from the virginal indian wife or the white man with extreme prejudice to the point of them being a total psycho' (Deewani_Aurat 2007) - 
and, though racism is rarely depicted in Indian movies set in Australia, where it is, as in Crook or Nala Damayanthi, it is White Australian males, the gora, who are the racists. Indeed, during the uproar over the attacks on Indian students, some contributors to Internet discussions related racism in Australia to Australia's White British past:

Look in the mirror brother. Australia was stolen from the innocent hands of Aboriginal People. And YOU came to India for trade and ruled us for 290 years. Maybe we all should keep quiet to the atrocities created by YOU in the world. (Indian in Aus 2010)

The recent attacks on people of Indian origin proves that the dormant 'criminal' instincts of Australians are now waking up - they are a race of criminals and deprived lot and will keep on murdering brown people to see a completely white Australia. Can't really blame them - they have the British racist blood and criminal instincts inherited from their ancestors. (Chittapavan 2010)

The idea that Australians are White and British is given voice in Crook by the fanatical Sikh, Samarth Singh (Arjan Bajwa), who, responding to his sister's call for Indians to respect Australian culture, dismisses the very idea that Australian culture has any value by reference to Australia's founding as a British penal colony: 'They are all descendants of criminals'. Though it condemns racism, Crook does not explicitly contest this view and if, as Andrew Jakubowicz has suggested, the Australians of Tourism Australia's promotional video, 'Nothing Like Australia', are White Australians - 'all Euro- 
Australians, overwhelmingly blond and young' (Jakubowicz 2010) - then tourism campaigns cannot challenge the view of Australia as a White British country, which is the very basis of the charge that Australians are racist. Or to put it another way, the image of Australia 'through the eyes of Indians' being sponsored by Australian support of Indian cinema reinforces the assumptions behind Indian charges of racism. If Aussies are White, then the Indian experience of White British imperialism can be readily invoked.

Third, by construing cosmopolitanism in terms of Ferraris rather than cultural diversity, Australian branding is complicit with the almost complete absence of nonWhite Australians in Indian movies, the occasional glimpse of Indigenous Australians in dance sequences being the main exception. African Americans appear as Americans in Indian films set in the United States, taking central (if stereotyped) roles in My Name is Khan (Johar, 2010), but the stories Bollywood tells are not in sympathy with the idea of a culturally diverse Australia and Australians of Chinese descent, numerically larger than those with Indian ancestry, are entirely absent from Indian cinema, either as Australians or as the victims of White racism. By similarly ignoring Australians of Indian or Chinese descent, Australian branding, like Indian movies, also ignores the lived experience of Australia's diverse diasporic population. Pnina Werbner has examined the experience of those from diasporic communities who are not members of the globalized rich in terms of an everyday or vernacular cosmopolitanism, pointing out that those forced to interact with others of different cultural backgrounds, such as migrant workers, may be more likely to understand and negotiate cultural difference; conversely, the wealthy, jet-setting élite, 'with their multiple passports and multiple homes in different countries, appear to lack the kind of cultural openness and sensitivity normally associated with 
cosmopolitanism' (Werbner 2006: 498). It therefore follows that, if there is a serious wish to promote Australia as comprising 'a variety of people who can speak a range of languages and possess a cultural understanding' (State Government of Victoria 2011), those who promote Australia overseas need to emphasize far more the cross-cultural understanding underpinning a vernacular cosmopolitanism and far less the Ferraris of the ‘consumable heroes' of Indian cinema.

The truth is, of course, that while purporting to represent 'the way contemporary Australia sees itself', government branding of Australia aims, first, to generate tourism and business migration, second, to generate employment directly and indirectly through film production and, lastly and almost as an afterthought, to aid understanding of Australia overseas. This is evident from the press releases reproduced in Australian newspapers whenever an Indian movie films in Australia, as in the report on From Sydney ... With Love in the Sydney Daily Telegraph:

From Sydney... With Love - the first Bollywood movie with Sydney in its title - began filming on Thursday and will employ about 500 Australian cast and crew in the next five weeks. [...] Head of the Australian production Anupam Sharma said it was great exposure for Sydney. [...] 'It will showcase Australia to hundreds of millions, and potentially a billion, people around the world'. (Yamine 2011)

Australian newspapers rarely if ever scrutinize these claims about the benefits of specific films to tourism or employment and merely reiterate the publicity statements circulated 
by the film-makers, including formulaic assertions about a film being the first in some or other respect. The claim that From Sydney... With Love is 'the first Bollywood movie with Sydney in its title' ignores the risk that this might be a disadvantage or that the film's story-line could damage Sydney's reputation overseas, while the claim that Salaam Namaste was 'the first Indian movie filmed entirely in Australia' (Phillips 2005) continues to be repeated despite being untrue (many of the interiors were filmed in Mumbai). Now Bhaag Milkha Bhaag is being claimed as 'the first ever biographical film to be made on a sports icon in India' (Anon. 2012a), a claim formulated in India but retailed in Australia for a diasporic audience, much as Australian newspapers in the 1950s retailed overseas news stories about British or American films to be shot in Australia (Hassam 2006). With federal and state governments, tourism commissions and newspapers all reproducing without question the film producers' publicity material, the production of Indian movies in Australia operates in such a rarefied atmosphere of mutual congratulation that the contribution of any specific film to actual tourist numbers, Australian employment or, indeed, the representation of the everyday experience of Australians has become secondary to the rhetoric. This is marketing to the marketers. In such an atmosphere, offering a critique of the claims made for Indian movies shot in Australia may seem disloyal or even unpatriotic, but if a free press is a vital component of democracy then the failure of journalists in particular to scrutinize government claims is a failure of democracy. In his critique of Tourism Australia's promotional video, 'Nothing Like Australia', Jakubowicz concedes that tourism images may be regarded as relatively harmless: 'No one is really expected to believe everything here, and the adverts should not be expected to contain anything that might put off 
prospective money spenders' (Jakubowicz 2010). Yet, as Jakubowicz also notes, it becomes a matter of public interest when fantasies about Australia are funded by the Australian taxpayer and managed through government corporations, and, as Aronczyk stresses, any lack of accountability by elected representatives devalues the status of citizenship:

By transposing authority from elected government officials to advertising and branding professionals, by replacing accountability with facilitation, and by fitting discussions of the nation into categories that privilege a particular kind of collective representation over diverse expression, nation branding affects the moral basis of national citizenship. (Aronczyk 2008: 43)

This transposition of authority from elected officials to business professionals is, of course, consistent with the neo-liberalism, which, since the 1980s, has sought to deliver government services through a combination of state-owned and private corporations. As a result, an ethos of public service, as glimpsed in Holt's suspicion of a purely commercial mentality, has been replaced by the evaluation of the public good purely in terms of financial outcomes. Yet even if shooting Indian films in Australia increases tourism and employment, an exclusive focus on economic benefits could still undermine the public good of Australia's reputation overseas, as Michael Gillan et al. noted of the promotion in India of Australian education as a revenue-earning global commodity (2003: 1395). Government claims about the benefits of showcasing Australia through Indian movies need to be investigated not just in financial terms but also in terms of the consequences 
for cultural relations, both within Australia and overseas, of government interests converging with those of business to promote a national brand.

Holding accountable those responsible for formulating the national brand is even more important when the branding process takes little account of the views of those who may be excluded from it, such as Australians of Indian descent who, like Peter Varghese, Australia's High Commissioner to India, identify more with Australia than India: 'I consider [...] my lifestyle, my values, my worldview to be very Australian' (Lall 2009). This exclusion of voices is in part due to the need to produce a selective and consistent brand image, a problem inherent in branding; as Aronczyk puts it, 'branding cannot account for the plurality of voices, legacies and competing visions of the nation-state' (Aronczyk 2008: 58). Yet voices may be excluded for economic reasons, as in the case of Peter Varghese, because some of the 'competing visions' are not judged saleable in the market for locations; or excluded for political reasons because they conflict with the ideology of those in power, as in the case of Australians of Indian or Chinese descent who have been victims of White racism. The adoption of lifestyle marketing and the consequent devaluation of the everyday experience of cultural diversity in Australia, of an Australian vernacular cosmopolitanism, is at heart a political, rather than a marketing, issue and one that can be effectively challenged only by holding to account those who are politically and, indeed, morally responsible for branding the nation. 


\section{References}

Ahmed, Nabila (2011), 'Tourism Australia gets real to calm Indian concerns', Australian, 28 November, http://www.theaustralian.com.au/business/tourism-australia-getsreal-to-calm-indian-concerns/story-e6frg8zx-1226207496540. Accessed 25 April 2012.

Akhtar, Farhan (2001), Dil Chahta Hai, Mumbai: Excel Entertainment.

Anand, Siddharth (2005), Salaam Namaste, Mumbai: Yash Raj Films. (2008), Bachna Ae Haseeno, Mumbai: Yash Raj Films.

Anon. (2009), 'Film planned on Indian student attacks', 9News, 16 June, http://news.ninemsn.com.au/entertainment/826225/film-planned-on-indianstudent-attacks. Accessed 1 May 2012. (2010), 'Deepika Padukone starring "Break Ke Baad" moved from Australia to SA', Sawf News, 7 January, http://www.sawfnews.com/Bollywood/62109.aspx. Accessed 13 April 2012.

(2011), 'Australia to be the lead star in a Bollywood love story on student's', Indian Herald, 20 September, http://indianherald.com.au/australian-news/australia-to-bethe-lead-star-in-bollywood/356/. Accessed 17 April 2012. (2012a), 'Bollywood movie Bhaag Milkha Bhaag to be filmed in Melbourne', Indian Herald, 29 February, http://indianherald.com.au/bollywood/bollywoodmovie-bhaag-milkha-bhaag-melbourne/1163/. Accessed 2 May 2012. 
(2012b), 'Hindi TV serials shot in foreign locations', Filmi Town,

http://www.filmitown.com/2012/01/07/hindi-tv-serials-shot-in-foreign-locations/. Accessed 29 April 2012.

Antonioni, Michelangelo (1966), Blow-Up, London: Bridge Films.

Aronczyk, Melissa (2007), 'New and improved nations: Branding national identity', in Craig Calhoun and Richard Sennett (ed.), Practicing Culture, London: Routledge, pp. 105-28.

(2008), “'Living the brand": Nationality, globality and the identity strategies of nation branding consultants', International Journal of Communication, 2, pp. 4165.

Ashok (2010), 'Australia condemns Indian student's killing' (comment), Deccan Herald, 4 January, http://www.deccanherald.com/content/44793/australia-condemnsindian-students-killing.html. Accessed 7 May 2012.

Aslam, Danish (2010), Break Ke Baad, Mumbai: Kunal Kohli Productions.

Australian Trade Commission (2011), 'About the brand', http://www.australiaunlimited.com/page/brand-australia/about-brand. Accessed 17 April 2012. (2012), “"Brand Australia” Launch - Malaysia', http://www.austrade.gov.au/BrandAustralia-Launch-Malaysia/default.aspx. Accessed 23 April 2012.

Batra, Pankaj (2010), Virsa, Mumbai: Wize Mindz Entertainment.

Chakravorty, Prateek (2012), From Sydney ... With Love, Mumbai: Pramod Films.

Cheah, Pheng (2006), 'Cosmopolitanism', Theory, Culture and Society, 23: 2-3, pp. 48696. 
Chittapavan, Hadacha (2010), 'Why can't Australian govt nab those behind attacks, asks India' (comment), Times of India, 9 January, http://timesofindia.indiatimes.com/india/Why-cant-Australian-govt-nab-thosebehind-attacks-asks-India/articleshow/5428376.cms. Accessed 5 May 2012.

D. Rajendra Babu, (2000), Preethse, Bangalore: Rockline Productions.

Deewani_Aurat (2007), 'Re: Namastey London (*ing Rishi Kapoor, Akshay Kumar, Katrina Kaif)', 21 July, BollyWHAT?, http://www.bollywhatforum.com/index.php?topic=16385.25. Accessed 1 May 2012.

Deshpande, Sudhanva (2005), 'The consumable hero of globalised India', in Raminder Kaur and Ajay J. Sinha (ed.), Bollyworld: Popular Indian Cinema through a Transnational Lens, New Delhi: Sage, pp. 186-203.

Film Victoria (2012), 'Locations', http://www.filmmelbournenow.com/cmslocations/index.phps. Accessed 13 April 2012. (n.d.a), 'Melbourne lifestyle', http://film.vic.gov.au/www/html/143-melbournelifestyle.asp. Accessed 22 September 2007. (n.d.b), 'FilmMelbourneNow', Film Victoria, Melbourne.

Fraser, Andrew (2009), 'Gong rejected from "racist" Australia', Australian, 1 June, p. 5. Gillan, Michael, Damachis, Bill and McGuire, John (2003), 'Australia in India: commodification and internationalisation of higher education', Economic and Political Weekly, 5 April, pp. 1395-403.

Hassam, Andrew (2006), 'From Kangaroo to Salaam Namaste: Australia as an exotic film location', Hungarian Journal of English and American Studies, 12: 1-2, pp. $19-27$. 
(2009), 'Melbourne, Indian popular cinema and the marketing of "an enviable cosmopolitan lifestyle"', Studies in South Asian Film \& Media, 1: 1, pp. 45-64. (2010), 'Interview with AK Tareen', in Andrew Hassam (ed.), Bollywood in Australia: Transnationalism and Cultural Production, Crawley, WA: UWA Publishing, pp. 177-83.

Indian in Aus (2010), 'Indian youth dies in Oz after being attacked' ('To Peter - the “White Australia" policy maker', comment), Express India, 3 January, http://www.expressindia.com/latest-news/Indian-youth-dies-in-Oz-after-beingattacked/562762/. Accessed 1 May 2012.

Jaisinghani, Bella (2004), 'Shooting with a business angle', Financial Express, 13 June, http://www.financialexpress.com/fe_full_story.php?content_id=61229. Accessed 12 April 2012.

Jakubowicz, Andrew (2010), 'On the beach: Selling Australia as a land or as a people', http://andrewjakubowicz.com/publications/on-the-beach-selling-australia-as-aland-or-as-a-people/. Accessed 1 May 2012.

Jeeva (2007), Unnale Unnale, Chennai: Aascar Films .

Joynson, Velma Joan (1995), 'Post-World War Two British migration to Australia: “The most pampered and protected of the intake?"', Ph.D. thesis, Parkville: University of Melbourne.

Kapoor, Ekta (2011-), Bade Achhe Lagte Hain, Mumbai: Balaji Telefilms.

Kapoor, Rishi (1999), Aa Ab Laut Chalen, Mumbai: R. K. Films. 
Kapur, Jyotsna and Pendakur, Manjunath (2007), 'The strange disappearance of Bombay from its own cinema: a case of imperialism or globalization?', Democratic Communiqué, 21: 1, pp. 43-59.

Kasebekar, Asha (2006), Pop Culture India! Media, Arts and Lifestyle, Santa Barbara, CA: ABC-CLIO.

Khamis, Susie (2012), 'Brand Australia: half-truths for a hard sell', Journal of Australian Studies, 36: 1, pp. 49-63.

Khan, Sajid (2007), Heyy Babyy, Mumbai: Nadiadwala Grandson Entertainment.

Kripalani, Coonoor (2006), 'Trendsetting and product placement in Bollywood film: Consumerism through consumption', New Cinemas: Journal of Contemporary Film, 4: 3, pp. 197-215.

Lall, Rashmee Roshan (2009), 'Australia is an advert for multi-culturalism, not me', Times of India, 11 October, http://articles.timesofindia.indiatimes.com/2009-1010/india/28100163_1_peter-varghese-australian-high-commissioner-indianstudents. Accessed 30 April 2012.

McKenty, Finn (2006), 'What's lifestyle marketing?', 2 October, http://lightheavyweight.blogspot.com/2006/10/whats-lifestyle-marketing.html. Accessed 4 August 2008.

Mehra, Rakeysh (in production), Bhaag Milkha Bhaag, Mumbai: Viacom18 Motion Pictures.

Minister for Trade (2009), 'Towards 2020 - the next decade of trade', press release, 26 August, http://www.trademinister.gov.au/speeches/2009/090826_t2020.html. Accessed 19 April 2012. 
(2010), ‘Australia unlimited: The nation's new brand', press release, 14 May, http://www.trademinister.gov.au/releases/2010/sc_100514.html. Accessed 23 April 2012.

Mouli (2003), Nala Damayanthi, Chennai: Raj Kamal Productions.

Johar, Karan (2010), My Name is Khan, Mumbai: Dharma Productions.

NSW Department of Trade and Investment, Regional Infrastructure and Services (2012), ‘Sydney’s lifestyle', http://www.sydneyaustralia.com/en/sydney-lifestyle. Accessed 24 April 2012.

Osuri, Goldie (2008), 'Ash-coloured whiteness: The transfiguration of Aishwarya Rai', South Asian Popular Culture, 6:2, pp. 109-23.

Phillips, Mark (2005), 'Bollywood on Bourke Street', Age, 13 May, http://www.theage.com.au/news/Film/Bollywood-on-BourkeStreet/2005/05/12/1115843307939.html. Accessed 2 May 2012.

Premier of Victoria (2012), 'Bollywood Biopic Bhaag Milkha Bhaag to be Filmed in Melbourne', press release, 22 February, http://www.premier.vic.gov.au/mediacentre/media-releases/3227-bollywood-biopic-bhaag-milkha-bhaagto-be-filmedin-melbourne.html. Accessed 17 April 2012.

Rao, Shakuntala (2007), 'The globalization of Bollywood: an ethnography of non-elite audiences in India', Communication Review, 10: 1, pp. 57-76.

Reed, Carol (1949), The Third Man, London: London Film Productions. rwguapa (2011), 'Brand Australia's “Australia Unlimited” launch video from M\&C Saatchi' (comment), YouTube, http://www.youtube.com/watch?v=Onab8IJLuLI. Accessed 5 May 2012. 
Soni, Prem (2009), Main Aurr Mrs. Khanna, Mumbai: Sohail Khan Productions.

State Government of Victoria (2011), 'Indian cinema to delight Victorian audiences', http://www.trade.vic.gov.au/content/indian-cinema-delight-victorian-audiences. Accessed 22 April 2012.

Suri, Mohit (2010), Crook: It's Good To Be Bad, Mumbai: Vishesh Films.

Tourism Australia (2011), 'Watch and hear what they have to say', http://www.australia.com/campaigns/in/namaste/index.html. Accessed 29 April 2012.

(n.d.), 'Tourism Australia launches advocacy campaign in India', press release, http://www.tourism.australia.com/en-au/news/6143.htm. Accessed 30 April 2012.

Tourism Victoria (2008), 'Victoria to star in another Bollywood film', Tourism Victoria Industry Newsletter, 10, 15 May, http://www.tourism.vic.gov.au/index.php?option=com_content\&task=view\&id=3 23. Accessed 14 August 2008.

Upe, Robert (2011), 'Bollywood builds bridge to tourism targets', Sydney Morning Herald, 19 November, http://www.smh.com.au/entertainment/movies/bollywoodbuilds-bridge-to-tourism-targets-20111118-1nn91.html. Accessed 29 April 2012.

Victorian Government (n.d.), Brand Victoria Resource Book, Melbourne: Department of Innovation, Industry and Regional Development.

Werbner, Pnina (2006), 'Vernacular cosmopolitanism', Theory, Culture and Society, 23: 2-3, pp. 496-98.

Yamine, Evelyn (2011), 'Bollywood film called from Sydney ... with love being made in Sydney by Prateek Chakravorty starring Bidita Bag', Daily Telegraph, 14 
November, http://www.dailytelegraph.com.au/entertainment/sydney-

confidential/bollywood-film-called-from-sydney-with-love-being-made-in-

sydney-by-prateek-chakravorty-starring-bidita-bag/story-e6frewz0-

1226193920927. Accessed 2 May 2012.

\section{Contributor details}

Andrew Hassam is Visiting Fellow in the School of English Literatures and Philosophy at the University of Wollongong. He is currently researching the production of Bollywood movies in Australia, as well as completing a monograph on changing Australian attitudes to British migrants. His most recent writing has appeared in Public History Review (2011), The Travels of Bollywood Cinema (Oxford University Press 2011) and The Magic of Bollywood (Sage 2012), and he is Editor of Bollywood in Australia: Transnationalism and Cultural Production (2010). He is a member of the Editorial Board of History Compass and a fellow of the UK Higher Education Academy. 